\title{
MODEL OF TRUST-BASED COOPERATIVE RELATIONSHIPS IN A SUPPLY CHAIN
}

\author{
Urszula RYCIUK ${ }^{\mathbb{D}}$, Joanicjusz NAZARKO (D* \\ International Department of Logistics and Service Engineering, \\ Faculty of Engineering Management, Bialystok University of Technology, Bialystok, Poland
}

Received 21 January 2020; accepted 06 May 2020

\begin{abstract}
The study aimed to find factors affecting the development of trust-based cooperative relationships and test the links between them. For this study, the research framework was based on the notion that a cooperative relationship in a supply chain required commitment, cooperation and trust among the supply chain partners, with trust as a critical element. The other assumption was that the selection of partners with specific qualities was conducive to building cooperative relationships. The research was conducted on a sample of 226 companies using the CATI technique. In the study structural equation modelling was used. The obtained results confirmed the positive impact of partner qualities on trust and adaptation, of adaptation on commitment, of trust on cooperation and commitment, and of commitment on cooperation. New measurement scales were used that expanded the range of factors that affect the successful building of trust-based cooperative relationships in a supply chain.
\end{abstract}

Keywords: supply chain, trust, commitment, cooperation, adaptation, partner qualities, confirmatory factor analysis (CFA), structural equation modelling (SEM), model.

JEL Classification: L2, L14, M11.

\section{Introduction}

Nowadays, the functioning and the development of enterprises to a large extent depend on relationships with other entities. Enterprises find it all the more difficult to undertake measures independently; hence, to gain and maintain their competitive advantage, they need to establish closer cooperation with their business partners (Min et al., 2005). Companies must build collaborative and long-term relationships with their customers and suppliers (Ting et al., 2007). Cooperation within a supply chain develops through repeated transactions and gradually evolves into a long-term partnership founded on loyalty and trust. Relational governance - the fear of tarnishing one's reputation, avoidance of the long-term relationship termination, the perspective for future cooperation as well as relational norms - may be

${ }^{\star}$ Corresponding author. E-mail: j.nazarko@pb.edu.pl 
a form of insurance against opportunistic behaviour. Supply chain governance determines how financial, material and human resources are allocated and flow within a chain (Gellynck \& Molnár, 2009); it is a framework for decision-making (Crișan, 2016). The term covers planned and conscious activities initiated by entities as well as unplanned elements emerging as a result of cooperation (Varoutsa \& Scapens, 2015).

The purpose of cooperation is to improve the long-term performance of individual partners and the supply chain as a whole. Trust is a main element that facilitates cooperation and the execution of common objectives; it is also a tool for limiting uncertainty and the risk associated with the functioning of enterprises in an unstable and unpredictable environment (Morgan \& Hunt, 1994). Fukuyama (1996) defined trust as a mechanism based on the assumption that other members of a specific community were characterised by honest and cooperative behaviour based on mutually observed standards. Trust is an alternative governance mechanism with regard to transactional costs of hierarchical control and contractual safeguards under a contract (Ejdys et al., 2019; Williamson, 1979).

Trust is indicated as the main antecedent of cooperation and commitment as well as the main element contributing to long-term orientation of supply relationships (Redondo \& Fierro, 2008). Among the elements determining that cooperative strategy can be successful and become the dominant strategy, cooperation should be mentioned, expressed as a pursuit of common goals, conflict resolution, joint planning, forecasting, commitment, communication, interdependence and adaptation (Fynes et al., 2004; Maloni \& Benton, 2000; Morgan \& Hunt, 1994). Cooperative relationships differ from a one-time market-based transaction as they extend over time, "possessing both a history and a future" (Stank \& Daugherty, 1997). Alignment of such relationships is difficult but allows getting greater benefits compared to a transactional relationship (Cao \& Zhang, 2011; Nyaga et al., 2010).

It is important to understand the factors that affect the development of successful relationships. However, cooperative processes have been insufficiently addressed by studies. The literature show that supply chain cooperative relationships could be understood as having such dimensions as trust, communication, adaptation and cooperation (Fynes et al., 2004; Su et al., 2008; Tian, 2018). Trust as main element contributing to cooperative behaviour is proved (Hausman \& Johnston, 2010; Lui et al., 2009; Martins et al., 2017). Commitment is demonstrated as main consequence of trust (Kwon \& Suh, 2004; Ryu et al., 2007; Saleh et al., 2014a; Talay \& Akdeniz, 2014). The consequence of trust is also adaptation and it can be expressed in the implementation of specific investments aimed at improving cooperation (Kwon \& Suh, 2004). However, there is a lack of analyzing relations between trust, commitment, adaptation and cooperation. This research, therefore, is to study links between main factors contributing to building trust-based cooperative relationships in supply chain. Additionally, new construct named partners qualities as antecedent of trust and adaptation was introduced. The assumption was that the selection of partners with favourable market opinion, well-known brand, sound financial standing and an offer of high-quality materials and services is conducive to building cooperative relationships.

The article provides definitions of the major theoretical constructs related to trust-based supply relationships. Then, it introduces the theoretical framework with hypotheses between constructs and describes the research methodology and outcomes of empirical investigation. 
Next, the article discusses the sample and the statistical methods used in the study to test the hypotheses and offers a discussion of the results and conclusions.

This study makes several contributions to the body of knowledge. First, it presents a new model of trust-based relationships and confirms that cooperation is influenced by commitment and trust, while commitment is influenced by trust and adaptation. Secondly, it introduces a new construct of partner qualities, which affect trust and adaptation. The paper also offers scales for construct measurement and checks their reliability.

\section{Literature review}

\subsection{Research background}

Supply chain management may be perceived as management of a relationship between customers and suppliers to create the highest value added for the final customer at the lowest cost of the entire supply chain functioning (Jüttner et al., 2007). According to the presented definition, shaping of proper supply chain relationships is crucial for its operation. The concept of supply chain management places emphasis on the need for integration and coordination of processes within and between enterprises (Yeung et al., 2009). Long-term trust-based cooperative relationships are indicated as fostering integration and bringing the most benefits (Cao \& Zhang, 2011).

The development of cooperation among entities in a supply chain is a gradual process. The conclusion of a single transaction marks the beginning of a relationship-building process. Issues that are particularly important for establishing relationships between partners in a supply chain are the availability of partners, price and recommendations made by other entities. At the initial stage, relationships are primarily transactional (an arm's length market), characterised by the pursuit of own benefits, the use of bargaining power, the focus on winning negotiations and the achievement of short-term goals. Relationships are characterised by high uncertainty and the likelihood of opportunistic behaviour as well as a low level or the lack of trust.

In the next stage, transactions can be repeated, gradually leading to the establishment of short-term relationships. If cooperation is successful and the companies fulfil their contractual agreements, the relationship can evolve into a trust-based long-term relationship, as over time, the companies create increasingly stronger and extensive economic and social ties. However, a trusted party will be credible on the condition it benefits from the relationship (Hardin, 2006). In the case of inter-organisational cooperation, benefits may be related to the willingness to maintain reputation or the perception of the relationship as potentially beneficial in the future. Any level of trust contains a risk that the partner will fail to follow through on the agreement (Currall \& Inkpen, 2002). The risk is accepted because of various benefits that result from building a relationship based on trust.

The literature contains numerous studies that attempt to demonstrate the superiority of cooperative relationships over transactional relationships. Kalwani and Narayandas (1995) compared the performance of companies having long-term cooperative relationships with suppliers and companies preferring the transactional approach. They concluded that the for- 
mer achieved better levels of sales and profitability. Ganesan (1994) proved that long-term supplier-customer relationships, by means of reducing transaction costs and limiting partner opportunism, allow for achieving a competitive advantage. Nyaga, Whipple and Lynch (2010) indicated that compared to transactional relationships, cooperative relationships resulted in greater benefits from cooperation, achieved a higher level of relationship satisfaction and improved business performance. Cao and Zhang (2011) claimed that cooperation between partners in a supply chain prevented the occurrence of the so-called "bullwhip effect" as well as improved the flexibility and innovativeness of the supply chain. The authors also demonstrated that benefits from cooperation depended on a win-win situation, in which all participants of the supply chain cooperated to achieve synergistic effects that fostered effective competition against other supply chains and affected the financial results achieved by enterprises.

Building trust-based relationships requires achieving an optimal level of trust that allows to achieve the greatest benefits (Ejdys, 2018). The following issues should be considered: missed opportunities related to the lack of trust; consequences of opportunistic behaviour; and consequences of possible excessive trust, associated with lower efficiency and the existence of a high risk of embezzlement. Trust should be increased to a level that is neither too low nor too high (to a "sweet spot of trust") because trusting partners are more open, less competitive and, therefore, theoretically, more creative and innovative. However, to achieve a high level of creativity, an additional level of internal tension is required, which does not occur in environments with the highest level of trust (Bidault \& Castello, 2010). The effectiveness of undertaken innovative activities is, therefore, the highest if the level of trust between entities is neither very low nor very high. It is worthwhile to note Covey's (2008) observation stating that the "lack of trust is associated with the biggest risk," which means that a weak tendency to trust and excessive caution are associated with the risk of slowing down operations, increasing costs, and losing the opportunity to cooperate and achieve synergy effects; hence, not the best solution. It is also important to highlight that the mechanism of governance is inseparable from a specific dyadic relationship established between two actors in a wider structure of supply chains (Swierczek, 2019).

Basically, supply chain management should be built on trust and commitment (Lin, 2014) while a high level of trust and commitment with a shared vision among supply chain partners is essential for collaboration (Spekman et al., 1998). According to Tian's study (2018), such dimensions as trust, commitment, communication and adaptation are typical for cooperative relationships in a supply chain. Morgan and Hunt (1994), however, underlined trust, commitment, communication and cooperation, and Maloni and Benton (2000) emphasised trust, commitment and cooperation. Meanwhile, Powers and Reagan (2007) identified trust, commitment, cooperation, satisfaction with the relationship and adaptation as factors influencing successful buyer-seller relationships.

Factors contributing to the development of cooperation in a supply chain are also indicated as determinants of the supply chain relationship quality (SCRQ). Trust and partner commitment are noted as the determinants of the partnership quality as they affect the strength of business-to-business relationships and supply chain integration (Lin, 2014). In 
turn, Fynes, de Búrca and Marshall (2004) defined the relationship quality as the extent to which parties are involved in a long-term cooperation and the implementation of processes related to trust, communication, adaptation and cooperation. The authors proved the impact of the relationship quality on supply chain results (customer satisfaction, speed and timeliness of deliveries, costs and flexibility).

The paper examines links between partner qualities and trust, partner qualities and adaptation, trust and commitment, adaptation and commitment, trust and cooperation, and commitment and cooperation.

\subsection{Partner qualities}

Initially, inter-organisational trust is primarily linked to the assessment of the credibility of entities, their resources and competences as well as the expected benefits of cooperation (competence and calculative trust). Due to the lack of previous experience, the central role in establishing trust is given to the brand, reputation of enterprises, references and recommendations by the partner with some history of cooperation with the enterprise, which is referred to as the principle of transitive trust (i.e. if A trusts $B$, and $B$ trusts $C$, then $A$ can trust $\mathrm{C}$ ). The literature mostly emphasises the influence of reputation on trust (Wong et al., 2005). Since gaining reputation is costly and time-consuming, it is easier to trust a company that has a good reputation and sees no benefit in risking actions that could damage it. In case of company bad reputation or lack of opinion on a given company on the market, the likelihood of establishing and engagement in long-term cooperation is low (Schmidt \& Wagner, 2019; Wood \& McDermott, 1999) as a reputable partner is unlikely to act opportunistically and would instead protect its name in the long run. This choice also seems less costly, as it requires fewer monitoring mechanisms (Lui et al., 2006).

Good reputation results from positive feelings and market opinions about the company as well as high-quality products and services offered. Also, a distinguishing feature of a trustworthy company is its brand, which differentiates company products from others and guarantees their quality. A brand not only consists of a name or a logo but also communication, behavioural and visual elements that define the enterprise. An element that reflects the credibility of the company is also its good standing and financial stability.

Costs and the need for additional resources make it impossible to establish close relationships with all partners in the supply chain; thus, it is necessary to select the right entities (Ploetner \& Ehret, 2006). Relationships built with entities that have well-known brands and good market reputation, offer high-quality products and services, and have sound financial standing will help to develop long-term relationships based on trust (Ryciuk, 2017). An analysis of the impact of trust and reputation on relationship-building in a supply chain has been offered by Suh and Houston (2010). The authors demonstrated the impact of both constructs on relationship commitment and the willingness to invest in its future. In this sense, the following propositions were established:

H1: Partner qualities have a positive influence on trust.

$\mathrm{H} 2$ : Partner qualities have a positive influence on adaptation. 


\subsection{Adaptation}

Adaptation occurs when supply chain partners change or adjust their resources and business processes to improve cooperation (Powers \& Reagan, 2007). Adaptation is a consequence of trust and can be expressed in the implementation of specific investments aimed at improving cooperation (Kwon \& Suh, 2004). Specific investments are dedicated to a given partner and cannot be easily transferred to other entities; therefore, they lose their value when cooperation is terminated. Investments in specific assets boost the importance of the relationship and, due to the cost of invested resources, reduce the risk of opportunistic behaviour while increasing trust and commitment (Lui et al., 2009). On the other hand, such investments may strengthen the dependence of one of the party to the relationship (the investing party) and therefore increase the risk of opportunistic behaviour on the side of the investee (LangfieldSmith, 2008). However, the likelihood of opportunistic behaviour depends on the type of relationship (Rokkan et al., 2003). In transactional relationships, the risk of opportunistic behaviour increases, while in cooperative relationships, specific investments limit the probability of opportunism. Trust and commitment can also be increased by adaptation activities undertaken by all parties involved in a relationship.

Relationship-specific asset results from a long-term investment in people, resources, and procedures (Ganesan, 1994; Gundlach et al., 1995; Morgan \& Hunt, 1994). It signals the desire to invest in an endurance of relationship (Lui et al., 2009; Yoon \& Moon, 2019). According to Patrucco, Moretto, Luzzini and Glas (2020), there is "no commitment, without investments". Hence, the following statement:

H3: Adaptation has a positive influence on commitment.

\subsection{Trust}

Trust is an essential element of cooperation. Cooperation either usually involves trust or it is associated with it and, by means of trust, it is possible to explain or predict the level of cooperation (Hardin, 2006). "Trust is the soul and foundation of supply chain management" and "it is also the key factor to maintain long-term cooperation" (Zhou et al., 2016, p. 1). The presence of trust in relationships between entities reduces uncertainty and the risk of actions taken (Morgan \& Hunt, 1994). It allows a more flexible reaction to changes in the environment (Cao \& Zhang, 2011). Trust reduces the risk of opportunistic behaviour and diminishes the need for a detailed contract or another mechanisms used to secure and monitor the execution of transactions (Semeijn et al., 2006).

Trust is primarily defined as a belief that a promise made by a business partner is credible, and that the partner behaves as the trusting party hopes, i.e. refraining from actions that might bring negative consequences (Friman et al., 2002). It is a belief in a business partner's honesty, reliability and competences that ensure the performance of a specific task (Blomqvist, 1997; Morgan \& Hunt, 1994; Sahay, 2003). Trusting someone means believing that the other party is guided by good intentions and is capable of meeting expectations (Hardin, 2006). Trust is an expectation that the partner will fulfil obligations and undertake actions that will bring benefits to the trusting party (Mayer et al., 1995; Sahay, 2003). 
Trust is strongly influenced by information sharing between supply chain partners (Redondo \& Fierro, 2008; Wong et al., 2005). Communication influences mutual understanding, conflict resolution, increasing trust and developing relationships (Goffin et al., 2006). Open, frequent, two-way and multi-level communication usually indicates the existence of close inter-organisational relationships (Cao \& Zhang, 2011). Doney and Cannon (1997) underlined the sharing of confidential information as a signal that the partner's motives and intentions were benevolent, and the party could be trusted. Therefore, open and frequent communication should be considered evidence (and an observable variable) that confirms trust (Ryciuk, 2017). Information exchange should be supported by advanced information systems and technologies (ICT) that enable the collection, processing and transmission of information (Szymczak et al., 2018).

Trust is essential in both transactional and cooperative relationships. Hence, trust-building measures are essential in every situation (Nyaga et al., 2010). The fundamental issue, however, is not the nature of a transaction, but its repetition. While a certain level of trust is necessary to conclude a transaction in each case, the importance of trust increases with the number of transactions concluded. A shared experience of cooperation affects the trust that exists in the relationship, while a certain level of trust determines the level of satisfaction with the relationship and the willingness to maintain it. Trust is indicated as an exceptional element of a relationship as it determines the establishment of cooperation (Heffernan, 2004), helps to facilitate joint planning and problem-solving (Claro et al., 2003), enables collaborative behaviours between supply chain partners (Yeung et al., 2009), and determine relationship satisfaction (Ryu et al., 2007).

Trust between partners can help to create a stable and committed relationship (Ryu et al., 2007; Saleh et al., 2014a, 2014b; Talay \& Akdeniz, 2014). "A successful supply chain relationship requires commitment among the supply chain partners, and trust is a critical element to sustain such commitment" (Kwon \& Suh, 2004, p. 5). Trust lies at the core of the mutual commitment of partners, and of the pursuit of the continuity of their relationship, i.e. it reflects a long-term orientation of the entities. It is one of the key factors contributing to long-term cooperation (Hausman \& Johnston, 2010). In this context, the following propositions regarding trust were established:

H4: Trust has a positive influence on cooperation.

H5: Trust has a positive influence on commitment.

\subsection{Commitment}

Commitment expresses a conviction that the existing relationship with a business partner is beneficial and that it is reasonable to take all possible actions to maintain it (Chen et al., 2011). This is an extent, to which a supplier feels obliged to continue working with a specific customer, which is a condition for building a lasting business relationship (Tanskanen \& Aminoff, 2015). Commitment suggests future orientation, which is why it is often referred to as a positive attitude towards the existence of the relationship in the future, an intention to build and maintain a relationship, especially in situations of interdependence between supply chain partners (Liu et al., 2017). Long-term orientation, which expresses the willingness 
of enterprises to make short-term sacrifices towards long-term benefits achieved thanks to a relationship, is a significant feature of commitment (Ryu et al., 2007). Ruyter, Moorman, and Lemmink (2001) indicated emotional commitment, connected with a generally positive perception of a specific partner, and calculative commitment, resulting from the lack of possibilities or high costs of substituting a specific business partner. The strength of relationships between partners in a supply chain also reflects the degree, to which enterprises incorporate informal links (Sarkar et al., 1998). Informal bonds arise over time and are the result of interaction between entities and reflect the degree of mutual friendship.

The main element affecting commitment is trust (trust-commitment theory). Trust and commitment are the key factors in supply chain management (Chen et al., 2011) that enable improvement of efficiency and effectiveness (Morgan \& Hunt, 1994). According to Sarkar, Aulakh and Cavusgil (1998), these are the main factors that determine the quality of a relationship.

Goodman and Dion (2001) demonstrated the impact of trust on distributor-producer relationships. However, the authors demonstrated that the level of commitment depended not only on trust but also on other factors, such as specific investments, communication, power, dependence and the ease of selling the product. $\mathrm{Wu}$, Chiag, $\mathrm{Wu}$, and $\mathrm{Tu}$ (2004) arrived at similar conclusions. The authors confirmed the impact of these factors on commitment and proved that the level of commitment determined the level of integration in the supply chain. Still, Nyaga, Whipple, and Lynch (2010) analysed the impact of trust on commitment and the effects of cooperation within a specific business relationship in a supply chain (satisfaction with the relationship, achieved results). They interpreted trust and commitment in the model as mediation variables whose impact on the supply chain performance depended on making specific investments (dedicated to a specific partner), sharing information as well as joint planning and problem-solving. Hence, the following statement:

H6: Commitment has a positive influence on cooperation.

\subsection{Cooperation}

In general, cooperation should be understood as acting jointly, in agreement, towards common goals, which otherwise would be unfeasible or costly (Brito et al., 2014). Cooperation is expressed by a degree of harmonious collaboration, understanding each other's behaviour and individual goals. Cooperation is also expressed through a joint selection of conflict resolution mechanisms (Ha et al., 2011). Cooperation assumes coordinated actions taken by exchange parties to achieve mutually beneficial behaviour in terms of flexibility, information exchange, and shared problem-solving (Anderson \& Narus, 1990; Morgan \& Hunt, 1994). The number and manner of conflict resolution affect the direction, in which the cooperation between the entities will develop. Conflicts between supply chain members arise as a result of conflicting interests, an unclear division of responsibilities, risks and benefits, the abuse of power and inadequate flow of information. Cooperation does not exclude the occurrence of conflicts in a relationship. A constructive conflict resolution may even increase trust, commitment and strengthen the relationship (Ruyter et al., 2001). Some authors, such as De Klerk (2012) and Martins, de Faria, Prearo, and Souza (2017), argued that it was trust and relationship commitment that led to cooperation between the partners. 
Cooperation is a consequence of trust in relationships (Hausman \& Johnston, 2010). Trust affects the level of cooperation as companies are unlikely to collaborate with an untrusted supplier (Redondo \& Fierro, 2008). Opportunism reduces the willingness of cooperation (Ting et al., 2007); therefore, trust should boost cooperation. For collaborative relationships to succeed, a joint relationship effort is essential with partners planning and coordinating activities as well as resolving problems together (Nyaga et al., 2010).

\section{Conceptual model}

The research framework for this study is based on the notion that a cooperative relationship in a supply chain requires commitment, cooperation and trust among the supply chain partners and trust is a critical element. The other assumption is that the selection of partners with specific qualities is conducive to building cooperative relationships. The theoretical expectations and findings from the literature review enabled the indication of a hypothetical model (Figure 1).

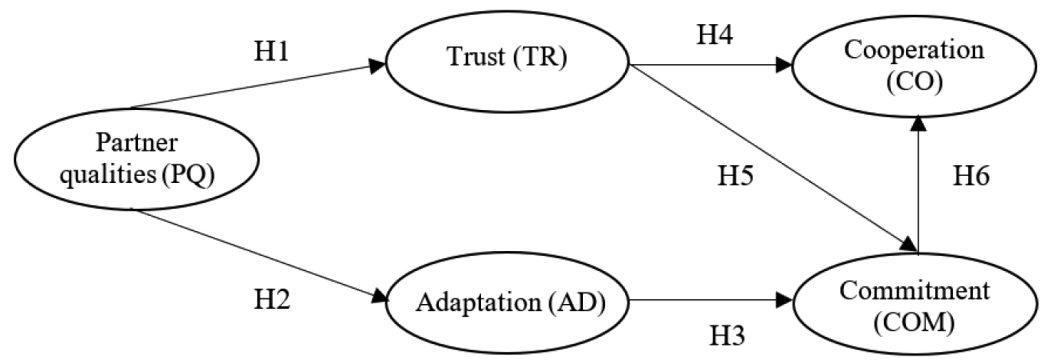

Figure 1. Hypothetical model

This study proposed a model of trust-based cooperative relationships in a supply chain composed of:

- trust based on information sharing, partner honesty, promise-keeping and competences required to perform the task and bring benefits;

- adaptation processes expressed in mutual actions striving for the improvement of cooperation: employee training, adjustment of processes, investments in resources;

- commitment manifested by long-term cooperation, attachment, being fond of partners, focus on future cooperation and readiness to make short-term sacrifices;

- partner qualities, such as favourable market opinion, well-known brand, sound financial standing and an offer of high-quality materials and services; and

- cooperation defined by common goals, joint planning, constructive conflict resolution and sharing of knowledge and experience.

\section{Research methodology}

\subsection{Structural equation modelling}

In social sciences, variables are often unobservable, difficult to describe and present in the form of a mathematical model. However, structural equation modelling (SEM) is a method 
that allows building the model using variables that are abstract and cannot be measured directly by a single item (latent variables, theoretical constructs, factors, dimensions), e.g. trust, commitment or cooperation. Latent variables are measured indirectly through observable variables (measurement variables, indicators, items), e.g. questionnaire statements.

SEM combines the regression analysis with the confirmatory factor analysis (CFA) and allows testing hypotheses with a high potential for the complexity of relationships between variables (regression and correlational). The most significant feature of structural equation modelling is the ability to estimate direct and indirect relationships among variables. The structural model shows dependencies between exogenous (independent, unexplained or unpredicted by other variables) and endogenous (dependent) variables. Another feature is the ability to include both the observable and the latent variables into the same analysis. SEM models are commonly presented as path diagrams (Figure 2) or as a set of Equations (1)-(9).

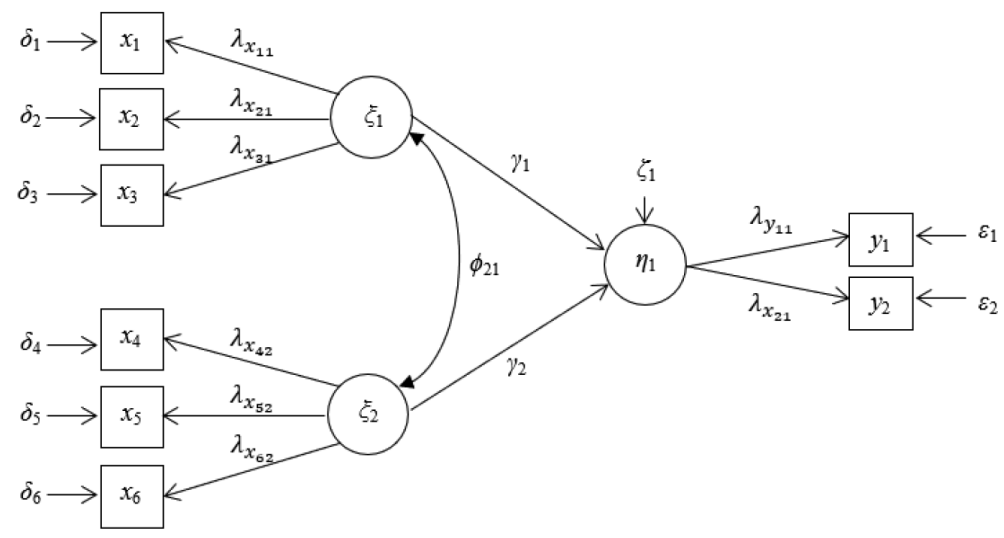

Figure 2. General structural model

The example of the model presents two exogenous latent variables $\xi_{1}$ and $\xi_{2}$ (the correlation between variables is marked $\phi_{21}$ ) and an endogenous latent variable $\eta_{1}$ :

$$
\eta_{1}=\gamma_{1} \xi_{1}+\gamma_{2} \xi_{2}+\zeta_{1}
$$

where, regression coefficients $\gamma_{1}$ and $\gamma_{2}$ determine the effect of exogenous variables $\xi_{1}$ and $\xi_{2}$ on endogenous variable $\eta_{1}$ (regression coefficients linking endogenous variables with other endogenous variables would be defined as $\beta_{i j}$ ).

The variables $\xi_{1}$ and $\xi_{2}$ are measured by exogenous observable variables $-x_{1}, x_{2}$, and $x_{3}$, as well as $x_{4}, x_{5}$, and $x_{6}$ respectively, and the variable $\eta_{1}$ - by endogenous observable variables $y_{1}$ and $y_{2}$ :

$$
\begin{aligned}
& x_{1}=\lambda_{x_{11}} \xi_{1}+\delta_{1} ; \\
& x_{2}=\lambda_{x_{21}} \xi_{1}+\delta_{2} ; \\
& x_{3}=\lambda_{x_{31}} \xi_{1}+\delta_{3} ; \\
& x_{4}=\lambda_{x_{42}} \xi_{2}+\delta_{4} ;
\end{aligned}
$$




$$
\begin{aligned}
& x_{5}=\lambda_{x_{52}} \xi_{2}+\delta_{5} ; \\
& x_{6}=\lambda_{x_{62}} \xi_{2}+\delta_{6} ; \\
& y_{1}=\lambda_{y_{11}} \eta_{1}+\varepsilon_{1} ; \\
& y_{2}=\lambda_{21} \eta_{1}+\varepsilon_{2} .
\end{aligned}
$$

Parameters $\lambda_{x_{11}}, \lambda_{x_{21}}, \lambda_{x_{31}}, \lambda_{x_{42}}, \lambda_{x_{52}}, \lambda_{x_{62}}, \lambda_{y_{11}}, \lambda_{y_{21}}$ are the factor loadings of a specific observable variable with the corresponding latent variable. The variables $\delta_{i}$ and $\varepsilon_{i}$ mean measurement errors of observable variables ( $x_{i}$ and $y_{i}$, respectively), while the unexplained variance of the endogenous latent variable $\eta_{1}$ (structural error, variation) is represented as $\zeta_{1}$.

A crucial aspect of using SEM is to test models that have strong theoretical foundations and CFA may be used as a final test in the process of developing new scales (Bowen \& Guo, 2012).

\subsection{Data collection}

The research was conducted using the Computer Assisted Telephone Interviews (CATI) technique. The research sample consisted of 226 companies (representatively from all Polish voivodeships): 113 enterprises with 10 to 49 employees, 77 with 50 to 200 employees and 36 with more than 200 employees. The research sample was selected in a quota random way. The sampling frame consisted of 13754 companies operating in the construction sector. Interviews were conducted with management staff using a structured questionnaire. The majority of respondents (72\%) had worked in the enterprise for more than five years. Only $7 \%$ of respondents had less than two years of work experience in the surveyed enterprise. The percentage of denials or unsuccessful contact attempt was high and reached $85 \%$.

The research constructs included trust, commitment, adaptation, cooperation and partner qualities comprising the total of 20 indicators (observable variables) (Table 1). The questionnaire was compiled by the authors based on the literature review. Trust was measured by five items relating to such trust antecedents as honesty, competence, promise-keeping, frequent and open information sharing, and expectations that the partner would meet obligations and his activities will be beneficial (based on Kwon \& Suh, 2004; Ryciuk, 2017; Svensson, 2001). Commitment was measured by five items relating to length of cooperation, desire to maintain it in the future, the sense of association with partners, fondness of partners, and assessment that the relationship is more important than short-term profits (partly based on Kwon \& Suh, 2004; Li et al., 2012; Lin, 2014; Ryciuk, 2017). Cooperation was measured by four items relating to conflicts solving, common goals and plans, and sharing of knowledge and experience (partly based on Martins et al., 2017; Su et al., 2008). Adaptation was measured by two items relating to joint activities, process adjustment and investments made for the improvement of cooperation (partly based on Fynes et al., 2004; Su et al., 2008). Partner qualities were measured by four items relating to favourable market opinion, well-known brands, sound financial standing, and the offer of high-quality materials and services (based on Ryciuk, 
2017; Wong \& Cheung, 2005). A seven-level Likert scale was used in the questionnaire to evaluate each indicator from "strongly disagree" (1) to "strongly agree" (7).

\subsection{Research process design}

The article provides definitions of the major theoretical constructs related to trust-based supply relationships. Then, it introduces the theoretical framework with hypotheses between constructs and describes research methodology and outcomes of empirical investigation. Next, the article discusses the sample and the statistical methods used in the study to test the hypotheses and offers a discussion of the results and conclusions. In the study structural equation modeling using the maximum likelihood method was used. Initially, the principal components analysis (PCA) was conducted. Then, the measurement model (the confirmatory factor analysis) and the structural model were estimated (the two-step approach by Anderson and Gerbing (1988)), (Figure 3).

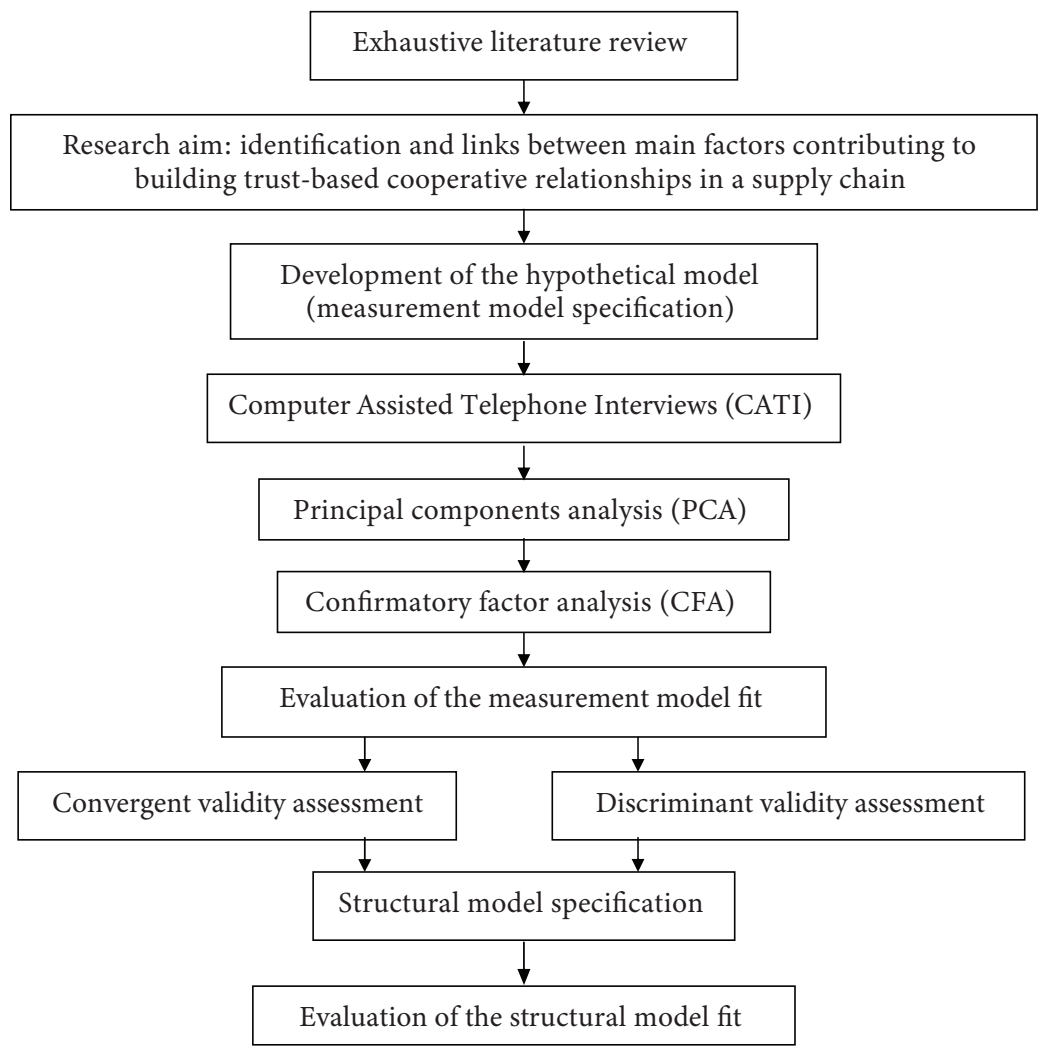

Figure 3. Methodology adopted for the study

The data analysis was based on the software IBM SPSS Statistics 21.0 with an additional module (AMOS) used for structural equation modelling. 


\section{Results}

In the first step, the principal components analysis (PCA) was conducted. The purpose of the analysis was to check the dimensionality of each research construct and to compare the selected questionnaire statements with items suggested by theory. The number of factors to retain was determined using the Kaiser rule (retain factors with eigenvalues higher than 1) and the scree plot analysis (the Cattell's scree test). The data were examined using PCA with the Varimax rotation method. Five identified constructs explained $61.45 \%$ of the total variance. All the items were loaded on the intended constructs.

Table 1. Confirmatory factor analysis results

\begin{tabular}{|c|c|c|c|}
\hline $\begin{array}{c}\text { Const- } \\
\text { ruct }\end{array}$ & & Statement & $\begin{array}{l}\text { Standardised } \\
\text { loading }(\lambda)^{*}\end{array}$ \\
\hline & TR1 & We are convinced that our partners are sincere & 0.83 \\
\hline & TR2 & $\begin{array}{l}\text { We believe that our partners know what they are doing and will } \\
\text { do their job well }\end{array}$ & 0.77 \\
\hline Trust & TR3 & Our partners usually keep their promises & 0.74 \\
\hline & TR4 & We believe that cooperation with our partners will be beneficial & 0.68 \\
\hline & TR5 & We share information with our partners often and openly & 0.59 \\
\hline & PQ1 & Our partners have a favourable opinion in the market & 0.87 \\
\hline Partner & PQ2 & Our partners offer high quality materials and services & 0.73 \\
\hline qualities & PQ3 & Our partners are businesses of sound financial standing & 0.71 \\
\hline & PQ4 & Our partners are businesses with well-known brands & 0.59 \\
\hline Adap- & AD1 & $\begin{array}{l}\text { Our partners work to make their cooperation with our company } \\
\text { better (train employees, adjust processes, invest in resources) }\end{array}$ & 0.56 \\
\hline tation & $\mathrm{AD} 2$ & $\begin{array}{l}\text { Our company works to make our cooperation with our partners } \\
\text { better (trains employees, adjusts processes, invests in resources) }\end{array}$ & 0.65 \\
\hline & $\mathrm{CO} 1$ & $\begin{array}{l}\text { We feel that we have a common goal, which is the reason to help } \\
\text { each other }\end{array}$ & 0.68 \\
\hline $\begin{array}{l}\text { Coo- } \\
\text { peration }\end{array}$ & $\mathrm{CO} 2$ & $\begin{array}{l}\text { In situations where we disagree with our partners, we do not } \\
\text { blame each other but look for the best solution to the problem } \\
\text { together with our partner }\end{array}$ & 0.57 \\
\hline & $\mathrm{CO} 3$ & Our partners share with us their knowledge and experience & 0.72 \\
\hline & $\mathrm{CO} 4$ & We plan our activities together with our partners & 0.55 \\
\hline & COM1 & $\begin{array}{l}\text { Even if we could drop our partners, we would not do it because } \\
\text { we feel associated with them }\end{array}$ & 0.62 \\
\hline & COM2 & $\begin{array}{l}\text { We would like to maintain our cooperation with our partners in } \\
\text { the future }\end{array}$ & 0.68 \\
\hline $\begin{array}{l}\text { Commit- } \\
\text { ment }\end{array}$ & COM3 & We are fond of our partners & 0.68 \\
\hline & COM4 & $\begin{array}{l}\text { We have been cooperating with our partners for rather a long } \\
\text { time }\end{array}$ & 0.52 \\
\hline & COM5 & $\begin{array}{l}\text { The relationship with our partners is more important than } \\
\text { short-term profits }\end{array}$ & 0.41 \\
\hline
\end{tabular}

Note: ${ }^{\star}$ Parameter significant at the level of 0.001 . 
In the next step, the measurement model was built. For this purpose, the confirmatory factor analysis (CFA) was used, which allows specifying the relationships between latent variables (theoretical constructs) and their observed variables (indicators). The latent variables of the measurement model were built based on reflective indicators. The role of each indicator is equivalent, and the elimination of one indicator does not change the nature of the latent variable but affects the reliability of the measurement.

In the CFA model fit evaluation the general model fit as well as the value and statistical significance of factor loadings were examined. Factor loadings above 0.71 were categorised as excellent; 0.63 - very good; 0.55 - good; 0.45 - sufficient and 0.32 - poor (Harrington, 2008). All factor loadings were significant ( $p<0.01)$. In most cases, the standardised regression weights linking a specific observable indicator with a latent variable were higher than 0.65 (did not exceed 0.55 in two cases only) (Table 1).

In the final version, indicators with the lowest value of factor loadings were excluded from the measurement model (namely, TR4, TR5, PQ4, CO4, COM4, and COM5).

In the next step the several statistical tests were used to determine how well the measurement model (compound of five latent variables and 14 observable variables) fits to the data. Chi-square $\chi^{2}=112.48$, degrees of freedom $\mathrm{df}=67$, the ratio for $\chi^{2} /$ degree of freedom was 1.68 (the recommended value is from 1 to 2 ), the root mean square error of approximation RMSEA $=0.05$ at $\mathrm{p}<0.05$ ( $<0.05$ indicates very good fit). The goodness-of-fit index GFI $=$ 0.94, the adjusted goodness-of-fit index AGFI $=0.90$, the comparative fit index $\mathrm{CFI}=0.96$, the normed fit index NFI $=0.91$; the incremental fit index IFI $=0.96$ exceeded the recommended value (>0.90). The parsimonious goodness-of-fit index PGFI $=0.60$ (as AGFI considering the complexity of the model) exceed the recommended value $>0.60$ (0.50) (Garson, 2015).

Subsequently, the convergent validity and the discriminant validity of the measurement model were evaluated. Average Variance Extracted (AVE), which is determined based on the values of standardised factor loadings, is an indicator used for assessing the convergent validity $\left(\mathrm{AVE}_{\eta}=\left(\sum_{i}\left(\lambda_{\eta i}\right) 2\right) /\left(\sum_{i}\left(\lambda_{\eta i}\right) 2+\sum_{i}\left(1-\lambda_{i}\right)\right)\right.$. The minimum acceptable AVE value is 0.5 (Fornell \& Larcker, 1981). A value below 0.5 means that on average, there is more error variance than the explained variance in the items constituting the structure of the latent variable. Composite Reliability (CR) was also used as an indicator of the convergent validity $\left(\mathrm{CR}_{\eta}=\left(\sum_{i} \lambda_{\eta i}\right)^{2} /\left(\left(\sum_{i} \lambda_{\eta i}\right)^{2}+\right.\right.$ $\left.\Sigma_{i}\left(1-\lambda_{i}\right)\right)$. A scale is considered homogeneous when CR is greater than 0.7 .

The reliability analysis for each extracted factor (measurement scale) was also made using the Cronbach's alpha $(\alpha)$. The alpha ranging was from 0 to 1 and the recommended threshold range was $0.6 \div 0.7$ (Nunnally \& Bernstein, 1994). Five theoretical constructs of the study had alphas higher than 0.6 and one construct had an alpha close to 0.6. This shows sufficient internal consistency reliability and the appropriateness of the scales for the measurement of the constructs in the study. Value of CR, AVE, Cronbach's alpha, mean and standard deviations for each item are given in Table 2.

To verify the discriminant validity, the analysis of the statistical significance of the change (growth) of the $\chi^{2}\left(\Delta \chi^{2}\right)$ statistics was carried out in a model, where one latent variable was created in lieu of two latent variables (using the same observable indicators). Single variables were created successively by determining the correlation equal to one for each pair of variables (Xiao et al., 2010). A statistically significant value $\Delta \chi^{2}$ indicates that the quality 
of matching the model with one latent variable is worse than with two latent variables. All performed tests showed significant differences in $\Delta \chi^{2}$, confirming the discriminant validity of the variables. The correlation between latent variables is shown in Table 3 .

Table 2. Confirmatory factor analysis results

\begin{tabular}{|c|c|c|c|c|c|c|c|}
\hline \multicolumn{2}{|c|}{ Construct } & \multirow{2}{*}{$\begin{array}{l}\text { Standardised } \\
\text { loading }(\lambda)^{*}\end{array}$} & \multirow[t]{2}{*}{ Mean } & \multirow{2}{*}{$\begin{array}{l}\text { Standard } \\
\text { deviation }\end{array}$} & \multirow[t]{2}{*}{ AVE } & \multirow[t]{2}{*}{$\mathrm{CR}$} & \multirow[t]{2}{*}{$\alpha$} \\
\hline \multirow{3}{*}{ Trust } & TR1 & & & & & & \\
\hline & TR2 & 0.78 & \multirow[t]{2}{*}{5.35} & \multirow[t]{2}{*}{1.06} & \multirow[t]{2}{*}{0.73} & \multirow[t]{2}{*}{0.82} & \multirow[t]{2}{*}{0.89} \\
\hline & TR3 & 0.74 & & & & & \\
\hline \multirow{3}{*}{$\begin{array}{l}\text { Partner } \\
\text { qualities }\end{array}$} & PQ1 & 0.87 & \multirow{3}{*}{5.28} & \multirow{3}{*}{1.05} & \multirow{3}{*}{0.71} & \multirow{3}{*}{0.80} & \multirow{3}{*}{0.88} \\
\hline & PQ2 & 0.72 & & & & & \\
\hline & PQ3 & 0.69 & & & & & \\
\hline \multirow{2}{*}{ Adaptation } & $\mathrm{AD} 1$ & 0.58 & \multirow{2}{*}{4.23} & \multirow{2}{*}{1.51} & \multirow{2}{*}{0.47} & \multirow{2}{*}{0.54} & \multirow{2}{*}{0.64} \\
\hline & $\mathrm{AD} 2$ & 0.62 & & & & & \\
\hline \multirow{3}{*}{ Cooperation } & $\mathrm{CO} 1$ & 0.66 & \multirow{3}{*}{5.31} & \multirow{3}{*}{1.10} & \multirow{3}{*}{0.54} & \multirow{3}{*}{0.68} & \multirow{3}{*}{0.78} \\
\hline & $\mathrm{CO} 2$ & 0.59 & & & & & \\
\hline & $\mathrm{CO} 3$ & 0.69 & & & & & \\
\hline \multirow{3}{*}{ Commitment } & COM1 & 0.59 & \multirow{3}{*}{5.17} & \multirow{3}{*}{1.09} & \multirow{3}{*}{0.54} & \multirow{3}{*}{0.68} & \multirow{3}{*}{0.78} \\
\hline & COM2 & 0.69 & & & & & \\
\hline & COM3 & 0.66 & & & & & \\
\hline
\end{tabular}

Note: ${ }^{\star}$ Parameter significant at the level of 0.001 .

Table 3. Correlation between latent variables

\begin{tabular}{|c|c|c|c|c|c|}
\hline & TR & PQ & CO & COM & AD \\
\hline TR & 1 & $0.652^{*}$ & $0.596^{*}$ & $0.540^{*}$ & $0.264^{*}$ \\
\hline PQ & & 1 & $0.501^{*}$ & $0.499^{*}$ & $0.253^{*}$ \\
\hline $\mathrm{CO}$ & & & 1 & $0.537^{*}$ & $0.325^{*}$ \\
\hline $\mathrm{COM}$ & & & & 1 & $0.388^{*}$ \\
\hline $\mathrm{AD}$ & & & & & 1 \\
\hline
\end{tabular}

Note: ${ }^{\star}$ Significant at the level of 0.001 .

The structural model was specified based on the conceptual model (Figure 1). The result of the estimation of the structural model is presented in Table 4.

In the structural model, seven paths proved to be statistically significant. The result supported the hypothetical model (Figure 4). The obtained results confirmed the positive impact of partner qualities on trust $(\gamma(\mathrm{PQ}, \mathrm{TR})=0.79$; $\mathrm{p}<0.001)$, partner qualities on adaptation $(\gamma(\mathrm{PQ}, \mathrm{AD})=0.44 ; \mathrm{p}<0.001)$, adaptation on commitment $(\gamma(\mathrm{AD}, \mathrm{COM})=0.47 ; \mathrm{p}<0.001)$, trust on cooperation $(\gamma(\mathrm{TR}, \mathrm{CO})=0.41 ; \mathrm{p}<0.001)$, trust on commitment $(\gamma(\mathrm{TR}, \mathrm{COM})=0.60$; $\mathrm{p}<0.004)$ and commitment on cooperation $(\gamma(\mathrm{COM}, \mathrm{CO})=0.49 ; \mathrm{p}<0.001)$ providing support for the hypotheses H1, H2, H3, H4, H5 and H6. 
Table 4. Results of the structural model

\begin{tabular}{|c|l|c|c|c|c|c|}
\hline $\begin{array}{c}\text { Hypo- } \\
\text { theses }\end{array}$ & \multicolumn{1}{|c|}{ Path } & $\begin{array}{c}\text { Standardised } \\
\text { path coefficient } \gamma\end{array}$ & $\begin{array}{c}\text { Standardised } \\
\text { error S. E. }\end{array}$ & $\begin{array}{c}\text { Critical } \\
\text { Ratio (CR) }\end{array}$ & p-value & Result \\
\hline H1 & $\begin{array}{l}\text { Partner qualities } \\
\rightarrow \text { Trust }\end{array}$ & 0.79 & 0.08 & 10.29 & 0.00 & Supported \\
\hline H2 & $\begin{array}{l}\text { Partner qualities } \\
\rightarrow \text { Adaptation }\end{array}$ & 0.44 & 0.12 & 4.16 & 0.00 & Supported \\
\hline H3 & $\begin{array}{l}\text { Adaptation } \rightarrow \\
\text { Commitment }\end{array}$ & 0.47 & 0.10 & 3.81 & 0.00 & Supported \\
\hline H4 & $\begin{array}{l}\text { Trust } \rightarrow \\
\text { Cooperation }\end{array}$ & 0.41 & 0.11 & 2.88 & 0.00 & Supported \\
\hline H5 & $\begin{array}{l}\text { Trust } \rightarrow \\
\text { Commitment }\end{array}$ & 0.60 & 0.08 & 6.36 & 0.00 & Supported \\
\hline H6 & $\begin{array}{l}\text { Commitment } \rightarrow \\
\text { Cooperation }\end{array}$ & 0.49 & 0.14 & 3.23 & 0.00 & Supported \\
\hline
\end{tabular}

The GFI value for the structural model was 0.93 , which means that the model explains $93 \%$ of the empirical variance of the covariance matrix. The value $\chi^{2} / \mathrm{df}=1.63$ and $\mathrm{RMSEA}=$ 0.05. Other goodness-of-fit statistics were IFI $=0.96$, AGFI $=0.90$ and CFI $=0.96$, which is indicative of good model fit. The assessment of the structural model was also based on the evaluation of the $\mathrm{R}^{2}$ (coefficient of determination) of the latent variables. The $\mathrm{R}^{2}$ shows the portion of the variance of the endogenous variable, which is explained by the model (Martins et al., 2017). The $\mathrm{R}^{2}$ of trust explained by partner qualities was $63 \%$, the $\mathrm{R}^{2}$ of commitment explained by trust and adaptation processes is $78 \%$, the $\mathrm{R}^{2}$ of cooperation explained by trust and commitment is $72 \%$, and the $\mathrm{R}^{2}$ of adaptation explained by partner qualities is $19 \%$. All values are large (Cohen, 1988).

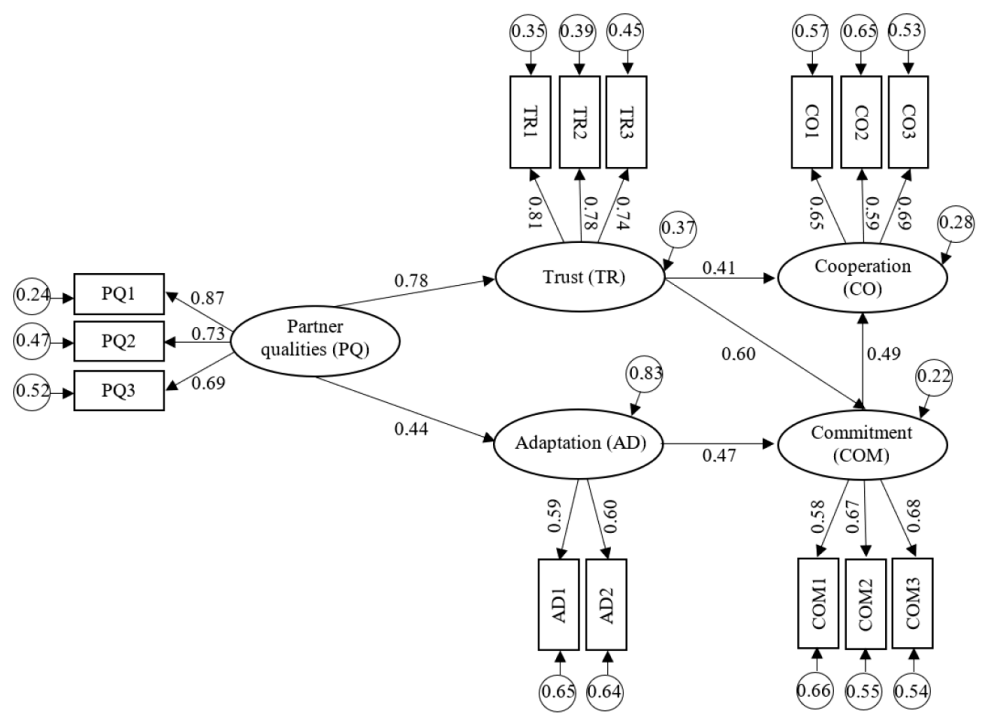

Figure 4. Structural model 
This study made several contributions to the body of knowledge. It confirmed that:

- trust is antecedent of commitment what was expressed by Kwon and Suh (2004), Martins, de Faria, Prearo, and Souza (2017), Ryu, Park, and Min (2007), Saleh, Ali, and Andaleeb (2014) and Talay and Akdeniz (2014);

- trust is antecedent of cooperation what is consistent with the suggestion of Hausman and Johnston (2010), Lui, Wong, and Liu (2009), Martins, de Faria, Prearo, and Souza (2017);

- commitment influence cooperation what was formulated by Martins, de Faria, Prearo, and Souza (2017).

Additionally, the influence of adaptation on commitment was proofed. Adaptation occurs when partner make efforts to make cooperation better through employees training, processes adjustment, investment in resource and may be understand as wider concept than specific investments. Usually asset specificity is described as trust antecedent (Kwon \& Suh, 2004; Lui et al., 2009; Nyaga et al., 2010). The study demonstrated the positive impact of partner qualities on trust and adaptation as well. The selection of supply chain partners that have a well-known brand, sound financial standing and offer high-quality materials and services is of vital importance, as proper selection of partners increases the probability for successful and satisfying cooperation.

\section{Conclusions}

Supply chain management means the need to shape relationships based on trust to achieve a synergistic result and, consequently, gain a competitive advantage by individual companies and the entire supply chain. There is a need to understand how cooperative relationships could be built. The study aimed to find factors affecting the development of trust-based cooperative relationships and test the links between them. The model studying the relationships between trust, commitment, adaptation and cooperation was introduced. Additionally, a new construct of partners qualities as an antecedent of trust and adaptation was tested. This study proposed a model related to mechanisms involved in the development of trust-based cooperative relationships impacted by the level of:

- trust based on partner honesty, promise-keeping, and competences required to perform the task;

- adaptation of processes expressed as mutual actions aimed at the improvement of cooperation;

- commitment manifested as an attachment to and being fond of partners and the focus on future cooperation;

- partner qualities, such as favourable market opinion, sound financial standing and the offer of high-quality materials and services;

- cooperation defined by common goals, constructive conflict resolution and sharing of knowledge and experience.

The article provided definitions of major theoretical constructs related to trust-based cooperative relationships in supply chain. Then, it introduced the theoretical framework with hypotheses between constructs and described outcomes of empirical investigation. The study used structural equation modelling. 
This study made several contributions to the body of knowledge. It confirmed that such dimensions as trust, commitment, cooperation and adaptation have a significant influence on successful supply chain relationships. Cooperation is influenced by commitment and trust, while commitment is influenced by trust and adaptation. The result extends existing studies of dimensions of cooperative relationships and the trust-commitment theory. The conclusions of this study is also that trust and adaptation are affected by partner qualities such as favourable market opinion, well-known brand, sound financial standing and an offer of high-quality materials and services what extend body of knowledge relating to influence of intangible assets on relationship building.

This research yielded several implications for managers and researchers. The content proposed in the paper may fill the research gap in trust-building and shaping inter-organisational relationships in supply chains in the construction and other sectors of the economy. The research problem is particularly interesting because trust and cooperation, especially in the context of growing uncertainty and constantly changing environment, play an increasingly important role in supply chains. Appropriate shaping of inter-organisational relationships can be a new instrument for increasing the competitive advantage. The model could be used to formulate underlying assumptions regarding measurement, assessment and shaping of the level of theoretical constructs in the model used.

The conceptualisation and operationalisation of theoretical constructs in the used model could serve as bases for strengthening cooperative relationships. It gives managers an opportunity to measure, assess and improve the adaptability, commitment, trust and, consequently, cooperation what is essential for moving from transactional short-term relationships to trustbased cooperative relationships and greater benefits achieving. Additionally, this study illustrates the importance of proper supply chain partner selection what increase the probability for successful and satisfying cooperation.

Some limitations of this study are noted. In the context of the described results, it is still necessary to take further action to improve the measurement of latent variables. The reliability analysis for each extracted factor showed that the scales are appropriate for measurement of the constructs used in the study. However, the reliability of measurement scales (especially adaptation) still could be improved. Additionally, data were collected from construction sector in Poland, so findings may be limited to national and sectoral context. Another limitation is that the study does not consider all dimensions of supply chain cooperative relationships. The model should be extended and include additional latent variables, such as bargaining position or exchange of information as separate constructs, not only the observable variables of trust. The other trends worth considering in cooperative relationships development theory is necessity to inclusion even better access to information, acquisition of information with better quality and higher transparency of information exchange.

Finally, the study relates only to relational mechanisms involved in building supply chain relations. It does not include the ambidexterity of supply chain governance mechanisms - a research area gaining more popularity. Further research should seek to capture the links between different relational and transactional governance mechanisms simultaneously occurring in supply chains. 


\section{Funding}

This work was supported by the funds of the Ministry of Science and Higher Education [WZ/WIZ/1/19].

\section{Author contributions}

U. Ryciuk was responsible for study conception and design. U. Ryciuk performed the statistical analysis and was responsible for data collection and analysis. J. Nazarko and U. Ryciuk were responsible for data interpretation, discussed the results and contributed to the final manuscript.

\section{Disclosure statement}

Authors have no competing financial, professional, or personal interests.

\section{References}

Anderson, J., \& Narus, J. (1990). A model of distributor firm and manufacturer firm working partnerships. Journal of Marketing, 54(1), 42-58. https://doi.org/10.2307/1252172

Anderson, J., \& Gerbing, D. W. (1988). Structural equation modeling in practice: A review and recommended two-step approach. Psychological Bulletin, 103(3), 411-423. https://doi.org/10.1037/0033-2909.103.3.411

Bidault, F., \& Castello, A. (2010). Why too much trust is death to innovation. MIT Sloan Management Review, 51(4), 33-38.

Blomqvist, K. (1997). The many faces of trust. Scandinavian Journal of Management, 13(3), 272-283. https://doi.org/10.1016/S0956-5221(97)84644-1

Brito, L. A. L., Brito, P. E. Z., \& Hashiba, L. H. (2014). What type of cooperation with suppliers and customers leads to superior performance? Journal of Business Research, 67(5), 952-959. https://doi.org/10.1016/j.jbusres.2013.07.015

Bowen, N. K., \& Guo, S. (2012). Structural equation modeling (1 $1^{\text {st }}$ ed.). Oxford University Press. https://doi.org/10.1093/acprof:oso/9780195367621.001.0001

Cao, M., \& Zhang, Q. (2011). Supply chain collaboration: Impact on collaborative advantage and firm performance. Journal of Operation Management, 29, 163-180.

https://doi.org/10.1016/j.jom.2010.12.008

Chen, J. V., Yen, D. C., Rajkumarc, T. M., \& Tomochko, N. A. (2011). The antecedent factors on trust and commitment in supply chain relationships. Computer Standards \& Interfaces, 33(3), 262-270. https://doi.org/10.1016/j.csi.2010.05.003

Claro, D. P., Hagelaar, G., \& Omta, O. (2003). The determinants of relational governance and performance: how to manage business relationships? Industrial Marketing Management, 32(8), 703-716. https://doi.org/10.1016/j.indmarman.2003.06.010

Cohen, J. (1988). Statistical power analysis for the behavioral sciences ( $2^{\text {nd }}$ ed.). Psychology Press.

Covey, M. R. (2008). The speed of trust: The one thing that changes everything. Free Press.

Crişan, E. (2016). A Separation between supply chain management and supply chain governance. Review of International Comparative Management, 17(3), 240-249. 
Currall, S. C., \& Inkpen, A. C. (2002). A multilevel approach to trust in joint ventures. Journal of International Business Studies, 33, 479-495. https://doi.org/10.1057/palgrave.jibs.8491027

De Klerk, S. (2012). Establishing and developing business networks: The importance of trust. African Journal of Business Management, 6(18), 5845-5856. https://doi.org/10.5897/AJBM11.2637

Doney, P. M., \& Cannon, J. P. (1997). An examination of the nature of trust in buyer-seller relationships. Journal of Marketing, 61(2), 35-61. https://doi.org/10.2307/1251829

Ejdys, J. (2018). Building technology trust in ICT application at a University. International Journal of Emerging Market, 13(5), 980-997. http://doi.org/10.1108/IJoEM-07-2017-0234

Ejdys, J., Ginevičius, R., Rozsa, Z., \& Janoskova, K. (2019). The role of perceived risk and security level in building trust in e-government solutions. E \& M Ekonomie a Management, 22(3), 220-235. https://doi.org/10.15240/tul/001/2019-3-014

Fornell, C., \& Larcker, D. F. (1981). Evaluating structural equation models with unobservable variables and measurement error. Journal of Marketing Research, 18(1), 39-50. https://doi.org/10.2307/3151312

Friman, M., Gärling, T., Millett, B., Mattsson, J., \& Johnston, R. (2002). An analysis of international business-to-business relationships based on the Commitment-Trust theory. Industrial Marketing Management, 31(5), 403-409. https://doi.org/10.1016/S0019-8501(01)00154-7

Fukuyama, F. (1996), Trust: The social virtues and the creation of prosperity (1st ed.). Free Press.

Fynes, B., de Búrca, S., \& Marshall, D. (2004). Environmental uncertainty, supply chain relationship quality and performance. Journal of Purchasing \& Supply Management, 10(9), 179-190. https://doi.org/10.1016/j.pursup.2004.11.003

Ganesan, S. (1994). Determinants of long-term orientation in buyer-seller relationships. Journal of Marketing, 58(2), 1-19. https://doi.org/10.2307/1252265

Garson, G. D. (2015), Structural equation modelling. Statistical Associates Publishers.

Gellynck, X., \& Molnár, A. (2009). Chain governance structures: The European traditional food sector. British Food Journal, 111(8), 762-775. https://doi.org/10.1108/00070700910980900

Goffin, K., Lemke, F., \& Szwejczewski, M. (2006). An exploratory study of "close" supplier-manufacturer relationships. Journal of Operations Management, 24(2), 189-209. https://doi.org/10.1016/j.jom.2005.05.003

Goodman, L. E., \& Dion, P. A. (2001). The determinants of commitment in the distributor-manufacturer relationship, Industrial Marketing Management, 30, 287-300. https://doi.org/10.1016/S0019-8501(99)00092-9

Gundlach, G., Achrol, R., \& Mentzer, J. (1995). The structure of commitment in exchange. Journal of Marketing, 59(1), 78-92. https://doi.org/10.2307/1252016

Ha, B. C., Park, Y. K., \& Cho, S. (2011). Suppliers' affective trust and trust in competency in buyers: Its effect on collaboration and logistics efficiency. International Journal of Operations \& Production Management, 31(1), 56-77. https://doi.org/10.1108/01443571111098744

Hardin, R. (2006). Trust (1st ed.). Polity Press.

Harrington, D. (2008). Confirmatory factor analysis (1st ed.). Oxford. https://doi.org/10.1093/acprof:oso/9780195339888.001.0001

Hausman, A., \& Johnston, W. J. (2010). The impact of coercive and non-coercive forms of influence on trust, commitment, and compliance in supply chains. Industrial Marketing Management, 39, 519-526. https://doi.org/10.1016/j.indmarman.2009.05.007

Heffernan, T. (2004). Trust formation in cross-cultural business-to-business relationships. Qualitative Market Research: An International Journal, 7(2), 114-125. https://doi.org/10.1108/13522750410530020

Jüttner, U., Christopher, M., \& Baker, S. (2007). Demand chain management - integrating marketing and supply chain management. Industrial Marketing Management, 36(3), 377-392.

https://doi.org/10.1016/j.indmarman.2005.10.003 
Kalwani, M. U., \& Narayandas, N. (1995). Long-term manufacturer-supplier relationships: Do they pay off for supplier firms?. Journal of Marketing, 59(1), 1-16. https://doi.org/10.2307/1252010

Kwon, I.-W. G., \& Suh, T. (2004). Factors affecting the level of trust and commitment in supply chain management. Journal of Supply Chain Management, 40(2), 4-14. https://doi.org/10.1111/j.1745-493X.2004.tb00165.x

Langfield-Smith, K. (2008). The relations between transactional characteristics, trust and risk in the start-up phase of a collaborative alliance. Management Accounting Research, 19(4), 344-364. https://doi.org/10.1016/j.mar.2008.09.001

Li, L., Ford, J. B., Zhai, X., \& Xu, L. (2012). Relational benefits and manufacturer satisfaction: an empirical study of logistics service in supply chain. International Journal of Production Research, 50(19), 5445-5459. https://doi.org/10.1080/00207543.2011.636388

Liu, Y., Luo, Y., Huang, Y., \& Yang, Q. (2017). A diagnostic model of private control and collective control in buyer-supplier relationships. Industrial Marketing Management, 63, 116-128. https://doi.org/10.1016/j.indmarman.2016.11.003

Lin, H.-F. (2014). The impact of socialization mechanisms and technological innovation capabilities on partnership quality and supply chain integration. Information Systems and e-Business Management, 12(2), 285-306. https://doi.org/10.1007/s10257-013-0226-z

Lui, S. S., Ngo, H., \& Hon, A. H. Y. (2006). Coercive strategy in interfirm cooperation: Mediating roles of interpersonal and interorganizational trust. Journal of Business Research, 59(4), 466-474. https://doi.org/10.1016/j.jbusres.2005.09.001

Lui, S. S., Wong, Y., \& Liu, W. (2009). Asset specificity roles in interfirm cooperation: Reducing opportunistic behavior or increasing cooperative behavior?. Journal of Business Research, 62(11), 1214-1219. https://doi.org/10.1016/j.jbusres.2008.08.003

Maloni, M., \& Benton, W. C. (2000). Power influence in the supply chain. Journal of Business Logistics, 21(1), 49-73.

Martins, D. M., de Faria, A. C., Prearo, L. C., \& Souza, A. A. G. (2017). The level of influence of trust, commitment, cooperation, and power in the interorganizational relationships of Brazilian credit cooperatives. Revista de Administração, 52(1), 47-58. https://doi.org/10.1016/j.rausp.2016.09.003

Mayer, R., Davis, J., \& Schoorman, F. (1995). An integrative model of organizational trust. The Academy of Management Review, 20(3), 709-734. https://doi.org/10.2307/258792

Min, S., Roath, A. S., Daugherty, P. J., Genchev, S. E., Chen, H., Arndt, A. D., \& Richey, R. G. (2005). Supply chain collaboration: what's happening? The International Journal of Logistics Management, 16(2), 237-256. https://doi.org/10.1108/09574090510634539

Morgan, R. M., \& Hunt, S. D. (1994). The commitment-trust theory of relationship marketing. Journal of Marketing, 58(3), 20-38. https://doi.org/10.2307/1252308

Nunnally, J. C., \& Bernstein, I.H. (1994). The assessment of reliability. Psychometric Theory, 3, 248-292.

Nyaga, G., Whipple, J., \& Lynch, D. (2010), Examining supply chain relationships: do buyer and supplier perspectives on collaborative relationships differ? Journal of Operations Management, 28(2), 101-114. https://doi.org/10.1016/j.jom.2009.07.005

Patrucco, A., Moretto, A., Luzzini, D., \& Glas, A. H. (2020). Obtaining supplier commitment: antecedents and performance outcomes. International Journal of Production Economics, 220, 107449. https://doi.org/10.1016/j.ijpe.2019.07.022

Ploetner, O., \& Ehret, M. (2006). From relationships to partnerships - new forms of cooperation between buyer and supplier. Industrial Marketing Management, 35(1), 4-9. https://doi.org/10.1016/j.indmarman.2005.08.006

Powers, T. L., \& Reagan, W. R (2007). Factors influencing successful buyer-seller relationships. Journal of Business Research, 60(12), 1234-1242. https://doi.org/10.1016/j.jbusres.2007.04.008 
Redondo, Y. P., \& Fierro, J. J. C. (2008). Educational level as moderating element of long-term orientation of supply relationships. Journal of Marketing Management, 24(3-4), 383-408. https://doi.org/10.1362/026725708X306158

Rokkan, A. I., Heide, J. B., \& Wathne, K. H. (2003). Specific investments in marketing relationships: Expropriation and bonding effects. Journal of Marketing Research, 15(2), 210-224. https://doi.org/10.1509/jmkr.40.2.210.19223

Ruyter, K., Moorman, L., \& Lemmink, J. (2001). Antecedents of commitment and trust in customersupplier relationships in high technology markets. Industrial Marketing Management, 30(3), 272273. https://doi.org/10.1016/S0019-8501(99)00091-7

Ryciuk, U. (2017). Identification of factors related to trust formation in construction supply chains. Procedia Engineering, 182, 627-634. https://doi.org/10.1016/j.proeng.2017.03.168

Ryu, S., Park, J. E., \& Min, S. (2007). Factors of determining long-term orientation in interfirm relationships. Journal of Business Research, 60(12), 1225-1233. https://doi.org/10.1016/j.jbusres.2006.09.031

Sahay, B. (2003). Understanding trust in supply chain relationships. Industrial Management \& Data Systems, 103(8), 553-563. https://doi.org/10.1108/02635570310497602

Saleh, M. A., Ali, M. Y., \& Andaleeb, S. S. (2014a). Explaining industrial importers' commitment from an emerging market perspective: Theoretical and managerial insights. Journal of Business \& Industrial Marketing, 29(1), 45-62. https://doi.org/10.1108/JBIM-09-2011-0116

Saleh, M. A., Ali, M. Y., \& Mavondo, F. T. (2014b). Drivers of importer trust and commitment: Evidence from a developing country. Journal of Business Research, 67(12), 2523-2530. https://doi.org/10.1016/j.jbusres.2014.03.010

Sarkar, M. B., Aulakh, P. S., \& Cavusgil, S. T. (1998). The strategic role of relational bonding in interorganizational collaborations: An empirical study of the global construction industry. Journal of International Management, 4(2), 85-107. https://doi.org/10.1016/S1075-4253(98)00009-X

Semeijn, J., Cao, L., \& Ghijsen, P. W. Th. (2006, January). Trust and its antecedents in supply chains: Evidence from a German buyers - Chinese suppliers' perspective [conference presentation]. The Fifth Annual International Business and Economy Conference, Honolulu, USA.

Schmidt, Ch. G., \& Wagner, S. M. (2019). Blockchain and supply chain relations: A transaction cost theory perspective. Journal of Purchasing and Supply Management, 25(4), 100552. https://doi.org/10.1016/j.pursup.2019.100552

Spekman, R. E., Kamauff, J. W., \& Myhr, N. (1998). An empirical investigation into supply chain management: A perspective on partnerships. International Journal of Physical Distribution \& Logistics Management, 28, 630-650. https://doi.org/10.1108/13598549810215379

Stank, T. P., \& Daugherty, P. J. (1997). The impact of operating environment on the formation of cooperative logistics relationships. Transportation Research Part E: Logistics and Transportation Review, 33(1), 53-65. https://doi.org/10.1016/S1366-5545(96)00005-1

Su, Q., Song, Y., Li, Z., \& Dang, J. (2008). The impact of supply chain relationship quality on cooperative strategy. Journal of Purchasing and Supply Management, 14, 263-272. https://doi.org/10.1016/j.pursup.2008.08.002

Suh, T., \& Houston, M. B. (2010). Distinguishing supplier reputation from trust in buyer-supplier relationships. Industrial Marketing Management, 39(5), 744-751. https://doi.org/10.1016/j.indmarman.2010.02.013

Svensson, G. (2001). Perceived trust towards suppliers and customers in supply chains of the Swedish automotive industry. International Journal of Physical Distribution \& Logistics Management, 31(9), 647-662. https://doi.org/10.1108/09600030110408152

Swierczek, A. (2019). Examining the link between the governance mechanisms and supply chain performance - an empirical study within the triadic context. Engineering Management in Production and Services, 11(3), 117-131. https://doi.org/10.2478/emj-2019-0026 
Szymczak, M., Ryciuk, U., Leończuk, D., Piotrowicz, W., Witkowski, K., Nazarko, J., \& Jakuszewicz, J. (2018). Key factors for information integration in the supply chain - measurement, technology and information characteristics. Journal of Business Economics and Management, 19(5), 759-776. https://doi.org/10.3846/jbem.2018.6359

Talay, M. B., \& Akdeniz, M. B. (2014). In time we trust?: The effects of duration on the dynamics of trust-building processes in inter-organizational relationships. Strategic Management Review, 8(1), 77-90.

Tanskanen, K., \& Aminoff, A. (2015). Buyer and supplier attractiveness in a strategic relationship - a dyadic multiple-case study. Industrial Marketing Management, 50, 128-141. https://doi.org/10.1016/j.indmarman.2015.04.011

Tian, A. (2018). The impact of supply chain cooperative relationship on performance: A knowledge management perspective. Journal of Service Science and Management, 11(1), 44-55. https://doi.org/10.4236/jssm.2018.111005

Ting, S., Chen, C., \& Bartholomew, D. (2007). An integrated study of entrepreneurs' opportunism. Journal of Business \& Industrial Marketing, 22(5), 322-335. https://doi.org/10.1108/08858620710773459

Varoutsa, E., \& Scapens, R. (2015). The governance of inter-organisational relationships during different supply chain maturity phases. Industrial Marketing Management, 46(1), 68-82. https://doi.org/10.1016/j.indmarman.2015.01.006

Williamson, O. (1979). Transaction-cost economics: The governance of contractual relations. The Journal of Law \& Economics, 22(2), 233-261. https://doi.org/10.1086/466942

Wong, P. S. P., \& Cheung, S. O. (2005). Structural Equation Model of trust and partnering success. Journal of Management in Engineering, 21(2), 70-80. https://doi.org/10.1061/(ASCE)0742-597X(2005)21:2(70)

Wong, P. S. P., Cheung, S. O., \& Ho, P. K. M. (2005). Contractor as trust initiator in construction partnering - prisoner's dilemma perspective. Journal of Construction Engineering and Management, 131(10), 1045-1053. https://doi.org/10.1061/(ASCE)0733-9364(2005)131:10(1045)

Wood, G., \& McDermott, P. (1999). Searching for trust in the UK construction industry: An interim view [conference presentation]. The CIB W92 International Procurement Conference, AIT, Thailand.

Wu, W.-Y., Chiag, C.-Y., Wu, Y.-J., \& Tu, H.-J. (2004). The influencing factors of commitment and business integration on supply chain management. Industrial Management \& Data Systems, 104(4), 322-333. https://doi.org/10.1108/02635570410530739

Yoon, J., \& Moon, J. (2019). The moderating effect of buyer purchasing strategy on the relationship between supplier transaction-specific investment and supplier firm performance. Journal of Business Research, 99, 516-523. https://doi.org/10.1016/j.jbusres.2017.08.022

Xiao, Y., Zheng, X., Pan, W., \& Xie, X. (2010). Trust, relationship commitment and cooperative performance: supply chain management. Chinese Management Studies, 4(3), 231-243. https://doi.org/10.1108/17506141011074129

Yeung, J. H. Y., Selen, W., Zhang, M., \& Huo, B. (2009). The effects of trust and coercive power on supplier integration. International Journal of Production Economics, 120(1), 66-78. https://doi.org/10.1016/j.ijpe.2008.07.014

Zhou, G., Fei, Y., \& Hu, J. (2016). The analysis of vertical transaction behavior and performance based on automobile brand trust in supply chain. Discrete Dynamics in Nature and Society, 4, 1-13. https://doi.org/10.1155/2016/4793851 